American Journal of Agricultural and Biological Sciences 6 (1): 29-32, 2011

ISSN 1557-4989

(C) 2010 Science Publications

\title{
Interactive Effects of the Feeding of Leucaena Leaves and Curcumin on Macronutrient Digestion and Nitrogen Balance in Beef Cattle
}

\author{
${ }^{1} \mathrm{C}$. Yuangklang, ${ }^{1} \mathrm{~J}$. Khotsakdee, ${ }^{1} \mathrm{~K}$. Vasupen, ${ }^{1} \mathrm{~S}$. Bureenok, ${ }^{1} \mathrm{~S}$. Wongsuthavas, \\ ${ }^{1}$ P. Panyakaew, ${ }^{2}$ A. Alhaidary, ${ }^{2}$ H.E. Mohamed and ${ }^{1,2}$ A.C. Beynen \\ ${ }^{1}$ Department of Animal Science, Faculty of Natural Resources, \\ Rajamangala University of Technology-Isan, Sakon Nakhon Campus, \\ Phang Khon, Sakon Nakhon 47160 Thailand \\ ${ }^{2}$ Department of Animal Production, College of Food and Agricultural Sciences, \\ King Saud University, Riyadh 11451, Kingdom of Saudi Arabia
}

\begin{abstract}
Problem statement: The feeding of curcumin to beef cattle has been shown to increase nitrogen retention and decrease the apparent digestibility of acid detergent fiber in beef cattle. It was suggested that there could be interactions between the effects of curcumin and the composition of the ration. Approach: In this study with beef cattle, concentrates without or with curcumin and low or high level of leucaena leaves were fed to assess the possible interactive effects. Apparent macronutrient digestibility and nitrogen balance were measured. Results: When the ration was curcumin free, an increase in the intake of leucaena leaf meal raised the group mean of apparent digestibility of dry matter, organic matter, crude fat, neutral and acid detergent fiber, but the opposite effect was seen for the curcumin-containing rations. Nitrogen retention was raised by extra intake of leucaena leaf meal, but only when the ration did not contain curcumin. The feeding of curcumin intake elevated nitrogen retention, the effect being greater for the ration with low content of leucaena. Conclusion: This study confirms that curcumin feeding has a stimulatory effect on nitrogen retention in beef cattle. The composition of the ration may determine the magnitude of the inhibitory effect of curcumin on the digestibility of acid detergent fiber.
\end{abstract}

Key words: Beef cattle, diet, leucaena leaves, curcumin, macronutrient digestibility, nitrogen balance, detergent fiber, concentrates, Analysis Of Variance (ANOVA)

\section{INTRODUCTION}

We have shown in beef cattle that the inclusion of curcumin in the ration produced an increase in nitrogen retention, which was associated with a decrease in the apparent digestibility of acid detergent fiber (Vorlaphim et al., 2010). The former effect of curcumin may be considered positive because an increase in the efficiency of protein utilization implies a lower requirement of protein and lower nitrogen emission per unit of ruminant production. However, a decrease in the digestibility of acid detergent fiber could point at limitation of the utilization of roughage which would have a negative impact on ruminant production. Thus, for the possible application of curcumin in ruminant nutrition it is relevant to identify ration compositions that maintain its positive effect on nitrogen utilization, but diminish its inhibitory effect on the degradation of acid detergent fiber.

The leaves of the Leucaena leucocephla tree have potential as a nitrogen source for ruminants. The rumen degradability characteristics of Leucaena leaves have been described (Gralak et al., 1997). Leucaena leaf meal as protein supplement has been shown to improve the feed quality of ruminants (Jabbar et al., 1997; Aregheore and Perera, 2004). It was thus considered of interest to study the interaction between curcumin and leucaena leaves with regard to macronutrient digestion and nitrogen balance in ruminants. In this study with beef cattle, concentrates without or with curcumin and low or high level of leucaena leaves were fed to assess the possible interactive effects.

Corresponding Author: C. Yuangklang, Department of Animal Science, Faculty of Natural Resources, Rajamangala University of Technology-Isan, Phang Khon, 47160 Sakon Nakhon, Thailand Tel: +66-42771460 Fax: +66-42771460 
Am. J. Agri. \& Biol. Sci., 6 (1): 29-32, 2011

\section{MATERIALS AND METHODS}

Four beef steers, aged about 2 years, were used according to a $2 \times 2$ factorial arrangement in a $4 \times 4$ Latin-square design. The initial body weight of the steers was on average $135 \mathrm{~kg}$. The dietary treatments consisted of concentrates containing 20 or $30 \%$ leucaena leaf meal that were formulated either without or with $0.1 \%$ curcumin. Extra leucaena leaf meal was added to the concentrate at the expense of soybean meal and cassava chips. The ingredient and analysed composition of the concentrates is shown in Table 1. As source of roughage, the steers received rice straw. The steers had free access to the rice straw and concentrates. Any feed left-overs were measured daily.

Each feeding period lasted 21 days. During the first 14 days of each period voluntary feed intake was measured while the animals were housed individually in pens. For the last 7 days of each period, the steers were transferred to metabolism crates. There were two days for adaptation to the crate and 5 days for separate and quantitative collection of urine and feces.
Feed and feces samples were and analyzed for proximate composition as described (Jansen et al., 2000; Alhaidary et al., 2010a,b; Mohamed et al., 2010; Yuangklang et al., 2010b). In urine samples the amount of nitrogen was analysed. Macronutrient digestibility was expressed as percentage of intake and calculated as (nutrient intake-nutrient in feces) $x$ nutrient intake $\mathrm{e}^{-1} \times 100$.

The data are presented as treatment means and SEM for four steers. Statistically significant effects of the levels of leucaena leaf meal and curcumin and their interaction, were identified with the use of Analysis Of Variance (ANOVA). Duncan's multiple range test was used to compare group means. The level of statistical significance was pre-set at $\mathrm{p}<0.05$.

\section{RESULTS}

Table 1 shows that the experimental concentrates had similar contents of crude protein and acid detergent fiber. The addition of extra leucaena leaf meal to the concentrate at the expense of soybean meal and cassava chips caused an increase in the contents of crude fat and neutral detergent fiber.

Table 1: Ingredient and analysed composition of the experimental concentrates

\begin{tabular}{|c|c|c|c|c|c|c|c|}
\hline & & \multicolumn{6}{|c|}{ Diet code (leucaena leaves:curcumin, $(\%: \%)$} \\
\hline & & 20:0 & $30: 0$ & & 20:0.1 & & $30: 0.1$ \\
\hline \multicolumn{8}{|l|}{ Ingredient, g $100^{-1} \mathrm{~g}$} \\
\hline Soybean meal & & 10.0 & 5.0 & & 10.0 & & 5.0 \\
\hline Leucaena leaves & & 20.0 & 30.0 & & 20.0 & & 30.0 \\
\hline Curcumin & & 0.0 & 0.0 & & 0.1 & & 0.1 \\
\hline Cassava chips & & 49.0 & 44.0 & & 48.9 & & 43.9 \\
\hline Constant components ${ }^{1}$ & & 21.0 & 21.0 & & 21.0 & & 21.0 \\
\hline Total & & 100.0 & 100.0 & & 100.0 & & 100.0 \\
\hline \multicolumn{8}{|c|}{ 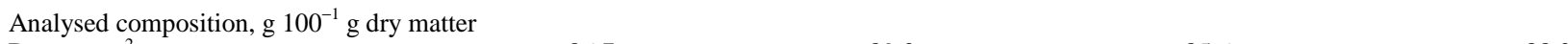 } \\
\hline Dry matter $^{2}$ & & 86.7 & 89.0 & & 85.6 & & 88.0 \\
\hline Organic matter & & 93.1 & 92.4 & & 89.5 & & 91.1 \\
\hline Crude protein & & 15.5 & 15.6 & & 16.0 & & 15.5 \\
\hline Crude fat & & 3.4 & 4.5 & & 3.4 & & 4.5 \\
\hline Neutral detergent fiber & & 21.1 & 25.6 & & 22.4 & & 26.0 \\
\hline Acid detergent fiber & & 15.0 & 15.6 & & 15.1 & & 15.6 \\
\hline \multicolumn{8}{|c|}{$\begin{array}{l}\text { : The constant components consisted of the following }(\mathrm{g}) \text { : rice bran, } 6.0 \text {; urea, } 2.0 \text {; molasses, } 7.0 \text {; salt, } 0.8 \text {; sulfur, } 0.2 \text {; dicalcium phosphate, } 1.0 \text {; } \\
\text { mineral premix, } 1.0 \text {; tallow; } 3.0 .^{2}: \text { Per } 100 \mathrm{~g} \text { of product }\end{array}$} \\
\hline \multicolumn{8}{|c|}{ Table 2: Feed intake by the beef cattle when fed the experimental rations } \\
\hline \multicolumn{8}{|c|}{ Diet code (leucaena leaves:curcumin, \%:\%) } \\
\hline & 20:0 & 30:0 & 20:0.1 & 30:0.1 & & SEM & Sign. ${ }^{1}$ \\
\hline \multicolumn{8}{|c|}{ Intake, $\mathrm{kg}$ dry matter day ${ }^{-1}$} \\
\hline Rice straw & 2.94 & 3.14 & 3.23 & 3.30 & & 0.03 & NS \\
\hline Concentrate & 1.29 & 1.34 & 1.31 & 1.24 & & 0.01 & $\mathrm{~L} \times \mathrm{C}$ \\
\hline $\begin{array}{l}\text { Total } \\
\text { Intake } \% \text { of bodv weig }\end{array}$ & 4.24 & 4.49 & 4.55 & 4.54 & & 0.02 & $\mathrm{~L} \times \mathrm{C}$ \\
\hline Rice straw & 1.91 & 2.04 & 2.02 & 2.15 & \multicolumn{2}{|c|}{ Intake, $\%$ of body weight } & NS \\
\hline Concentrate & 0.86 & 0.88 & 0.83 & 0.81 & & 0.01 & NS \\
\hline Total & 2.77 & 2.92 & 2.85 & 2.97 & & 0.02 & NS \\
\hline \multicolumn{8}{|c|}{ Intake, $\mathrm{g} \mathrm{kg}^{-1}$ metabolic body weight } \\
\hline Rice straw & 67.4 & 72.0 & 71.8 & 75.9 & & 0.60 & NS \\
\hline Concentrate & 30.1 & 30.8 & 29.5 & 26.9 & & 0.17 & NS \\
\hline Total & 97.5 & 102.8 & 101.3 & 102.8 & & 0.59 & NS \\
\hline
\end{tabular}


Am. J. Agri. \& Biol. Sci., 6 (1): 29-32, 2011

Table 3: Apparent digestibility of macronutrients in the beef cattle when fed the experimental rations

\begin{tabular}{|c|c|c|c|c|c|c|}
\hline & \multicolumn{6}{|c|}{ Diet code (leucaena leaves:curcumin, \%:\%) } \\
\hline & 20:0 & $30: 0$ & 20:0.1 & 30:0.1 & SEM & Sign. ${ }^{1}$ \\
\hline \multicolumn{7}{|l|}{ Digestibility, $\%$ of intake } \\
\hline Dry matter & 64.9 & 73.5 & 71.6 & 69.6 & 0.37 & NS \\
\hline Organic matter & 67.4 & 75.5 & 73.6 & 71.6 & 0.33 & NS \\
\hline Crude fat & $71.5^{\mathrm{b}}$ & $80.0^{\mathrm{a}}$ & $78.1^{\text {ba }}$ & $75.3^{\mathrm{b}}$ & 0.29 & $\mathrm{~L}$ \\
\hline Neutral detergent fiber & 49.8 & 62.1 & 58.8 & 55.0 & 0.48 & NS \\
\hline Acid detergent fiber & 37.3 & 42.2 & 38.2 & 34.4 & 0.71 & $\mathrm{~L}$ \\
\hline
\end{tabular}

Table 4: Nitrogen balance in the beef cattle when fed the experimental rations

\begin{tabular}{|c|c|c|c|c|c|c|}
\hline & \multicolumn{6}{|c|}{ Diet code (leucaena leaves:curcumin, \%:\%) } \\
\hline & 20:0 & $30: 0$ & 20:0.1 & 30:0.1 & SEM & Sign. ${ }^{1}$ \\
\hline \multicolumn{7}{|l|}{$\mathrm{N}$ intake, $\mathrm{g} \mathrm{day}^{-1}$} \\
\hline Rice straw & 8.5 & 8.8 & 9.1 & 8.8 & 2.96 & NS \\
\hline Concentrate & 31.7 & 32.8 & 32.1 & 30.3 & 5.51 & NS \\
\hline Total & 40.2 & 41.5 & 41.2 & 39.1 & 6.25 & NS \\
\hline \multicolumn{7}{|l|}{$\mathrm{N}$ excretion, $\mathrm{g} \mathrm{day}^{-1}$} \\
\hline Feces & 21.6 & 18.2 & 16.8 & 15.3 & 2.40 & $\mathrm{C}$ \\
\hline Urine & 6.1 & 6.7 & 5.9 & 5.1 & 1.64 & NS \\
\hline $\mathrm{N}$ absorption, $\mathrm{g} \mathrm{day}^{-1}$ & 18.7 & 23.4 & 24.4 & 23.8 & 2.20 & $\mathrm{C}$ \\
\hline $\mathrm{N}$ balance, $\mathrm{g} \mathrm{day}^{-1}$ & 12.6 & 16.7 & 18.5 & 18.7 & 2.42 & $\mathrm{C}$ \\
\hline $\mathrm{N}$ absorption, $\%$ of intake & 46.4 & 56.2 & 59.3 & 60.8 & 3.28 & NS \\
\hline
\end{tabular}

The addition of extra leucaena meal to the concentrate tended to increase rice straw intake slightly (Table 2). There were interactions between leucaena meal and curcumin with regard to concentrate and total feed intake expressed as kg dry matter per day. When either expressed as percentage of body weight or per $\mathrm{kg}$ metabolic weight, the intake of rice straw, concentrate and total feed did not differ between the three dietary treatments.

When the ration did not contain curcumin, an increase in the intake of leucaena leaf meal raised the group mean of apparent digestibility of dry matter, organic matter, crude fat, neutral and acid detergent fiber (Table 3). However, for the curcumin-containing rations there was a decrease in macronutrient digestibility when extra leucaena leaf meal was ingested. There were no significant interactions between the intake of leucaena leaf meal and curcumin with regard to the digestibility of dry matter, organic matter, crude fat, neutral and acid detergent fiber. The dietary level of leucaena meal significantly increased the digestibility of crude fat and acid detergent fiber.

Nitrogen intakes with the four experimental rations were similar (Table 4). Group mean fecal nitrogen excretion was lowered by the intake of extra leucaena leaf meal and by curcumin, but only the lowering effect of curcumin reached statistical significance. Urinary nitrogen excretion was not affected by the dietary level of leucaena leaf meal, but tended to be diminished by curcumin intake. Nitrogen absorption and balance were numerically raised by extra intake of leucaena leaf meal, but only when the ration did not contain curcumin. The feeding of curcumin caused a significant increase in nitrogen absorption, but only when the ration contained the low level of leucaena leaf meal the increase was substantial. Curcumin intake elevated nitrogen balance, the effect being greater for the ration with low content of leucaena.

\section{DISCUSSION}

In our previous study on the effect of curcumin feeding on nitrogen balance in beef steers, we used rations containing urea-treated rice straw and concentrates based on cassava, soybean meal and corn (Vorlaphim et al., 2010). In that study, curcumin feeding was found to enhance nitrogen retention. This study confirms the stimulatory effect of curcumin on nitrogen retention in beef cattle. The curcumin-induced increase in nitrogen retention was greater for the ration with the low level of leucaena leaf meal. The addition of extra leucaena to the concentrate also produced an increase in nitrogen retention which may explain the smaller effect of curcumin on nitrogen retention for the ration with high level of leucaena. It should be noted 
that the exchange of multiple ingredients in the concentrates with low and high level of leucaena leaf meal complicates the interpretation of the nitrogen balance data (Yuangklang et al., 2010a).

In our earlier study, the intake of curcumin caused a decrease in the apparent digestibility of acid detergent fiber (Vorlaphim et al., 2010). In the present study, curcumin also reduced the digestibility of acid detergent fiber, but only when the ration contained the high inclusion level of leucaena leaf meal. This observation indicates that the composition of the ration may determine the effect of curcumin on the digestibility of acid detergent fiber or the lack of such an effect. It should be noted that the feeding of extra leucaena leaf meal had mediated an increase in the digestibility of acid detergent fiber. Thus, it would seem that curcumin had counteracted the stimulatory effect of leucaena leaf meal on the digestibility of acid detergent fiber.

There were interactions between the dietary levels of leucaena leaf meal and curcumin with regard to the digestibility of macronutrients. An increase in the intake of leucaena leaf meal raised macronutrient digestibility when the ration was curcumin free, but caused a lowering when the ration contained curcumin. We have shown that curcumin feeding produced an increase in the total counts of ruminal bacteria (Vorlaphim et al., 2010). It would be logical to suggest that the curcumin-induced increase in ruminal bacteria had increased the digestibility of macronutrients so that the impact of the high digestibility of leucaena leaf meal was no longer detectable. However, this does not explain why the feeding of extra leucana leaf meal caused a decrease in macronutrient digestibility when curcumin was added to the ration.

\section{CONCLUSION}

This study confirms that curcumin feeding has a stimulatory effect on nitrogen retention in beef cattle. It was also confirmed that curcumin reduced the digestibility of acid detergent fiber, but this was only seen when the ration was rich in leucaena leaf meal. It is suggested that the composition of the ration may determine the magnitude of the inhibitory effect of curcumin on the digestibility of acid detergent fiber.

\section{REFERENCES}

Alhaidary, A., H.E. Mohamed and A.C. Beynen, 2010a. Nephrocalcinosis in female rats fed diets containing either pectin or cellulose. Am. J. Anim. Vet. Sci. 5: 111-116. DOI: 10.3844/.2010.111.116
Alhaidary, A., H.E. Mohamed and A.C. Beynen, 2010b. Impact of dietary fat type and amount on growth performance and serum cholesterol in rabbits. Am. J. Anim.Vet. Sci. 5: 60-64. DOI: 10.3844/.2010.60.64

Aregheore, E.M. and D. Perera, 2004. Effect of supplementation of a basal diet of maize stover with Erythrina variegata, Gliricidia sepium or Leucaena leucocephala on feed intake and digestibility by goats. Trop. Anim. Health Prod., 36: 175-189. PMID: 14998316

Gralak, M.A T. Kamalu, M.A. Von Keyserlingk and G.W. Kulasek, 1997. Rumen dry matter and crude protein degradability of extracted or untreated oilseeds and Leucaena leucocephala leaves. Arch Tierernahr, 50: 173-185. PMID: 9227808

Jabbar, M.A., L. Reynolds, A. Larbi and J. Smith, 1997. Nutritional and economic benefits of Leucaena and Gliricidia as feed supplements for small ruminants in humid West Africa. Trop. Anim. Health Prod., 29: 35-47. PMID: 9090017

Mohamed, H.E., A. Alhaidary and A.C. Beynen, 2010. Nephrocalcinosis in female rats fed diets containing either pectin, galacturonic acid or glucose. Am. J. Anim. Vet. Sci. 5: 117-120. DOI: 10.3844/.2010.117.120

Vorlaphim, T., M. Phonvisay, J. Khotsakdee, K. Vasupen and S. Bureenok et al., 2010. Influence of dietary curcumin on rumen fermentation, macronutrient digestion and nitrogen balance in beef cattle. Am. J. Agric. Biol. Sci., 6: 7-11.

Yuangklang, C., C. Wachirapakorn, H.E. Mohamed, A. Alhaidary and A.C. Beynen, 2010b. Effect of calcium supplementation on growth, nutrient digestibility and fecal Lactobacilli in dairy calves. Am. J. Anim. Vet. Sci., 5: 127-131. DOI: 10.3844/.2010.127.131

Yuangklang, C., K. Vasupen, S. Wongsuthavas, S. Bureenok and P. Panyakaew et al., 2010a. Effect of replacement of soybean meal by dried tomato pomace on rumen fermentation and nitrogen metabolism in beef cattle. Am. J. Agric. Biol. Sci., 5: 256-260. DOI: $10.3844 / .2010 .256 .260$ 